UDC 613.28:61-057.875

https://doi.org/10.26641/2307-0404.2019.2.170155

L.B. Yeltsova, S.T. Omelchuk, A.A. Petrosian

\section{HYGIENIC ASSESSMENT OF FREQUENCY OF CONSUMING FOOD PRODUCTS OF ANIMAL ORIGIN IN THE DIET OF MEDICAL STUDENTS AND RATIONALE OF WAYS OF ITS CORRECTION}

O.O. Bogomolets National Medical University

department of Hygiene and Ecology $\mathrm{N} 4$

Peremogy av., 34, Kyiv, 03057, Ukraine

Национальный медицинский университет имени А.А. Богомольйа

кафедра гигиены и экологии № 4

пр. Победы, 34, Киев, 03057, Украина

e-mail: ieltsovaluba@ukr.net

\author{
Цитування: Медичні перспективи. 2019. Т. 24, № 2. С. 73-82 \\ Cited: Medicni perspektivi. 2019;24(2):73-82
}

Key words: frequency of consumption, map questionnaire, food products of animal origin, diet, alimentary diseases, ways of correction, medical students

Ключові слова: частота споживання, опитувальна карта, харчові продукти тваринного походження, раціон харчування, аліментарні захворювання, шляхи корекиії, студенти-медики

Ключевые слова: частота потребления, карта-опросник, пищевые продукты животного происхождения, раџион питания, алиментарные заболевания, пути коррекции, студенть-медики

\begin{abstract}
Hygienic assessment of frequency of consuming food products of animal origin in the diet of medical students and rationale of ways of its correction. Yeltsova L.B. Omelchuk S.T. Petrosian A.A. Availability of various healthy food products in the student's diet and conscious student's choice represents the best way of prevention of the alimentary and alimentary-associated diseases, preservation and promotion of health. The aim of the study: hygienic assessment of frequency of consuming food products of animal origin by medical students in order to prevent alimentary diseases by means of correction of diet. The authors studied medical students' diet using map questionnaire with the subsequent data assessment. The study includes the data of 858 respondents, students of the $2^{\text {nd }}, 4^{\text {th }}$ and $6^{\text {th }}$ years of study of medical faculties of O.O. Bogomolets National Medical University. Random sampling was used. The age of the respondents ranges between 18 and 25 years, 570 females and 288 males. Frequency of consumption was estimated according to the following categories: consuming of food products of animal origin once a day or even more often, consuming them almost every day, consuming them once a week, consuming them several times a week, consuming them once or several times a month, consuming them rarely or never. The study assessed frequency of consumption of such product groups as: meat and meat products, fish and seafood, milk and dairy products, eggs and fatty products. The authors have established that one third of the respondents, regardless of their gender and year of study, consume meat and meat products once a day or almost every day. From $20 \%$ (the $2^{\text {nd }}$ year of study) to $28 \%$ (the $6^{\text {th }}$ year of study) of male respondents and from $13 \%$ (the $2^{\text {nd }}$ year of study) to $21 \%$ (the $6^{\text {th }}$ year of study) of female respondents consume fish and seafood once a week or several times a week. Less than 30\% of both male and female respondents, without regard to the year of study, consume milk and dairy products once a day or even more often. About $20 \%$ of male respondents and from $10 \%$ (the $2^{\text {nd }}$ year of study) to $25 \%$ (the $6^{\text {th }}$ year of study) of female respondents consume eggs daily. 16-18\% of male respondents and 6-10\% of female respondents consume fatty products (butter, lard) daily or almost every day. The obtained results make it possible to conclude that more than 2/3 of the medical students' diets according to the frequency of consuming food products of animal origin do not correspond to the National recommendations on nutrition precisely by the frequency of their consumption [12, 13]. This may lead to polynutrient deficiency and development of alimentary diseases, which proves the necessity of correction of medical students' diet.
\end{abstract}

Реферат. Гігієнічна оцінка частоти споживання харчових продуктів тваринного походження в раціоні студентів-медиків та обгрунтування шляхів його корекції. Сльцова Л.Б., Омельчук С.Т., Петросян А.А. Забезпечення доступності до різноманітних здорових продуктів у раціоні студентів, їх вільний самостійний та свідомий вибір - це один з найкращчих заходів профілактики аліментарних та аліментарнозалежних 
захворювань, збереження та зміцнення здоров'я. Мета роботи: гігієнічна оцінка частоти споживання харчових продуктів тваринного походження студентами-медиками з метою профілактики аліментарних захворювань шляхом корекиї раціонів харчування. За допомогою опитувальної карти була зібрана інформація та проведена оцінка результатів дослідження раціонів студентів-медиків. В анкетуванні взяли участь 858 респондентів 2, 4, 6 курсів медичних факультетів НМУ імені О.О. Богомольия. Анкетування проводилось анонімно за попередньою поінформованою згодою респондентів. Формування вибірки довільне. Вік респондентів від 18 до 25 років, серед них 570 респондентів жіночої статі та 288 респондентів чоловічої статі. У роботі представлені результати оцінки частоти споживання харчових продуктів тваринного походження в раціоні студентів-медиків. Частота споживання харчових продуктів тваринного походження оиінювалась відносно споживання протягом дня, тижня, місяия та проводилась за такою шкалою: споживання один раз на день або майже щзодня, один раз на тиждень, кілька разів на тиждень, один або декілька разів на місяџь, рідко або ніколи. Проводилась очінка частоти споживання таких груп харчових продуктів: м'яса та м'ясних продуктів, риби та продуктів моря, молока та молочних продуктів, яєць та жировмісних продуктів. Встановлено, щуо лише третина респондентів, незалежно від статі та курсу навчання, використовуе в рачіоні м'ясо та м'ясні продукти один раз на день або майже щзоня. Від 20\% респондентів чоловічої статі (2 курс) до 28\% (6 курс) та від 13\% респондентів жіночої статі (2 курс) до $21 \%$ (6 курс) використовують у своєму раціоні рибу та продукти моря один або декілька разів на тиждень. Менше 30\% респондентів, незалежно від статі та курсу навчання, один раз на день або майже щзодня включають у свій раціон молоко та молочні продукти. Щоденно використовують у раціоні курячі яйця близько 20\% респондентів чоловічої статі та від 10\% (2 курс) до 25\% (6 курс) респондентів жіночої статі. Щоденно або майже щзодня включають у свій раціон жировмісні продукти (масло вершкове, сало) 16-18\% респондентів чоловічої статі та 6-10\% респондентів жіночої статі. Отримані результати дають можливість зробити висновок про те, щзо більше 2/3 раціонів студентів-медиків за частотою споживання харчових продуктів тваринного походження не відповідають начіональним рекомендачіям щуоо харчування населення саме за частотою їх споживання [12, 13]. Ситуація, щчо склалась може призвести до виникнення полінутрієнтних дефіцитів харчових речовин та в подальшому аліментарних захворювань, що підтверджує необхідність проведення иілеспрямованої корекиії раціонів харчування студентів-медиків за частотою споживання харчових продуктів тваринного походження.

The presence of food products of major groups in the diet of students makes it possible to provide the body with all essential nutrients and thereby ensure high levels of working capacity, including mental activity. Diversity, balance and moderation in the use of the main food groups in the diet with a certain frequency is one of the basic principles of a healthy and rational nutrition of the population, including students. Eating an adequate amount of food every day due to a balanced set of the main food groups can significantly reduce the risk of nutritional, nutritional-related diseases and the subsequent risks of developing cardiovascular and oncological diseases and diabetes, the most common among Ukrainians [9, 11, 12, 14]. Food products of animal origin - meat and meat products, fish and seafood, milk and dairy products, eggs, butter, lard are the main sources of high-grade proteins with a high content of essential (essential) amino acids, essential fats (PUFA W3), group B vitamins, biotin, folacin, pantothenic acid, fat-soluble vitamins $\mathrm{A}, \mathrm{E}, \mathrm{D}$, chelated forms of hematopoietic elements $(\mathrm{Fe}, \mathrm{Cu}, \mathrm{Co}$, $\mathrm{Mn}, \mathrm{Zn}), \mathrm{Ca}$ chelate forms, and iodine $[1,10,15]$.

The introduction in Ukraine of the new norms of the physiological needs of the population in basic nutrients and energy, modern recommendations on healthy nutrition $[12,13]$ updates the monitoring of nutrition and health of the population, students and medical students including $[3,4,6,7,8]$, with the aim of developing and introducing scientifically based nutritional recommendations into their daily lives.

The purpose of the work is a hygienic assessment of the frequency of consumption of food products of animal origin by medical students in order to prevent alimentary diseases by correcting diet.

\section{MATERIALS AND METHODS OF RESEARCH}

To conduct the study, modern adequate methods were used, namely: analytical, questionnaire-based, statistical (data were processed using the program IBM SPSS Statistiks Base v.22, which has official licensing for processing medical data in Ukraine). A questionnaire-chart developed by the Department of Nutrition Hygiene (Hygiene and Ecology No. 4) of A.A. Bogomolets National Medical University was used [5] which passed an expert assessment of leading experts of the institutions of Ukraine in the field of food hygiene, gastroenterology and dietetics.

Study Design: Cross-sectional blind study. The survey was conducted anonymously by prior agreement of the respondents. Inclusion criteria: medical 
students of 2, 4, 6 courses. The exclusion criteria: students being on dietary, therapeutic or preventive nutrition temporarily or for a long time, preferring non-traditional types of food (vegetarians, rawatarians), pregnant ( 2 and 3 trimesters), those who have chronic diseases in the stage of sub- and decompensation.

The survey was conducted in a short-time period, from December 2016 to March 2017 due to the fact that during this period (autumn-winter, winterspring) the manifestations of nutritional deficiencies in the body of students are the most pronounced. The survey was conducted by pre-prepared interviewers (the period of preparation was 2 weeks).

With the help of questionnaire-chart 858 respondents were surveyed. The theoretical statistical error of the random sample of 858 respondents from the total population of 10,000 with a confidence probability $(\mathrm{P})=0.95$ does not exceed $0.032(3.2 \%)$. Medical students of 2, 4, 6 courses of medical faculties № 3, 4 and the faculty of training doctors for the Armed Forces of Ukraine are among them. Sampling is arbitrary. The age of the respondents is from 18 to 25 years, of which 570 are female respondents and 288 are male respondents. Students of the 2 nd course: 213 females, 126 males; students of the 4th course: 192 females, males -89 ; students of the 6th course -165 females, males -73 .

\section{RESULTS AND DISCUSSION}

With the help of a questionnaire-chart, we collected and evaluated results of study of medical students' diet. In previous works, the results of evaluation of the questionnaire-chart by some of its sections were presented $[2,5]$. In this paper, we present the results of evaluating frequency of consumption of foods of animal origin in their diet. The frequency of consumption of food of animal origin was evaluated by the following scale: consumption once a day or more often, almost every day, once a week, several times a week, once or several times a month, rarely or never. The frequency of consumption of such food groups as meat and meat products, fish and seafood, milk and dairy products, eggs, fat-containing products - butter, lard (taking into account the food preferences of Ukrainians) was evaluated..

When assessing the frequency of consumption of meat and meat products, it was revealed that $31.75 \%$ and $27.75 \%$ respectively of male-respondents of the 2nd course and $38.0 \%$ and $26.8 \%$ respectively of female-respondents of the 2 nd course consume them daily or almost every day; once a week or several times a week $-8.75 \%$ and $19.0 \%$ of the male-res- pondents and $7.5 \%$ and $14.0 \%$ of the female-respondents; once or several times a month, rarely or never $-7.95 \%$ and $4.8 \%$ of male-respondents and $8.5 \%$ and $5.2 \%$ of female-respondents; every day or almost every day $-12.35 \%$ and $24.7 \%$ respectively of male- respondents of the 4th course and $22.4 \%$ and $21.9 \%$ respectively of female-respondents of the 4th course; once a week or several times a week $28.1 \%$ and $18.0 \%$ of male-respondents and $27.1 \%$ and $20.3 \%$ of female-respondents; once or several times a month, rarely or never $-14.6 \%$ and $2.25 \%$ of male-respondents and $4.7 \%$ and $3.6 \%$ of femalerespondents; daily or almost every day $-34.25 \%$ and $37.0 \%$, respectively of male-respondents of the 6 th course and $27.3 \%$ and $35.15 \%$ of female-respondents, respectively, of the 6th course; once a week or several times a week $-6.85 \%$ and $13.7 \%$ of malerespondents and $15.15 \%$ and $10.9 \%$ of female-respondents; once or several times a month, rarely or never $-8.2 \%$ and $0.0 \%$ of male-respondents and $7.26 \%$ and $4.24 \%$ of female-respondents. Data on the frequency of consumption of meat and meat products are presented in the form of a graph (Fig. 1).

When assessing the frequency of consumption of fish and seafood, it was found that $7.15 \%$ and $11.9 \%$, respectively, of male- respondents of the 2 nd course and $4.7 \%$ and $9.4 \%$, respectively, of femalerespondents of the 2 nd course consume them daily or almost every day; once a week or several times a week $-26.2 \%$ and $21.4 \%$ of male-respondents and $20.6 \%$ and $13.6 \%$ of female-respondents; once or several times a month, rarely or never $-15.9 \%$ and $17.45 \%$ of male-respondents and $29.7 \%$ and $22.0 \%$ of female-respondents; daily or almost every day $7.85 \%$ and $7.85 \%$, respectively, of male-respondents of the 4th course and $4.15 \%$ and $8.9 \%$ of femalerespondents, respectively, of the 4th course; once or several times a week $-20.25 \%$ and $25.85 \%$ of malerespondents and $22.9 \%$ and $16.65 \%$ of femalerespondents; once or more times a month, rarely or never $-16.85 \%$ and $21.35 \%$ of male-respondents and $37.0 \%$ and $10.4 \%$ of female respondents; every day or almost every day $-2.75 \%$ and $12.3 \%$, respectively, of male-respondents of the 6th course and $2.7 \%$ and $10.9 \%$ of female-respondents, respectively, of the 6th course; once a week or several timeës a week $-28.75 \%$ and $26.0 \%$ of malerespondents and $26.1 \%$ and $21.3 \%$ of femalerespondents; once or several times a month, rarely or never $-20.5 \%$ and $9.7 \%$ of male-respondents and $18.2 \%$ and $20.8 \%$ of female-respondents. Data on the frequency of consumption of fish and seafood are presented in the form of a graph (Fig. 2). 

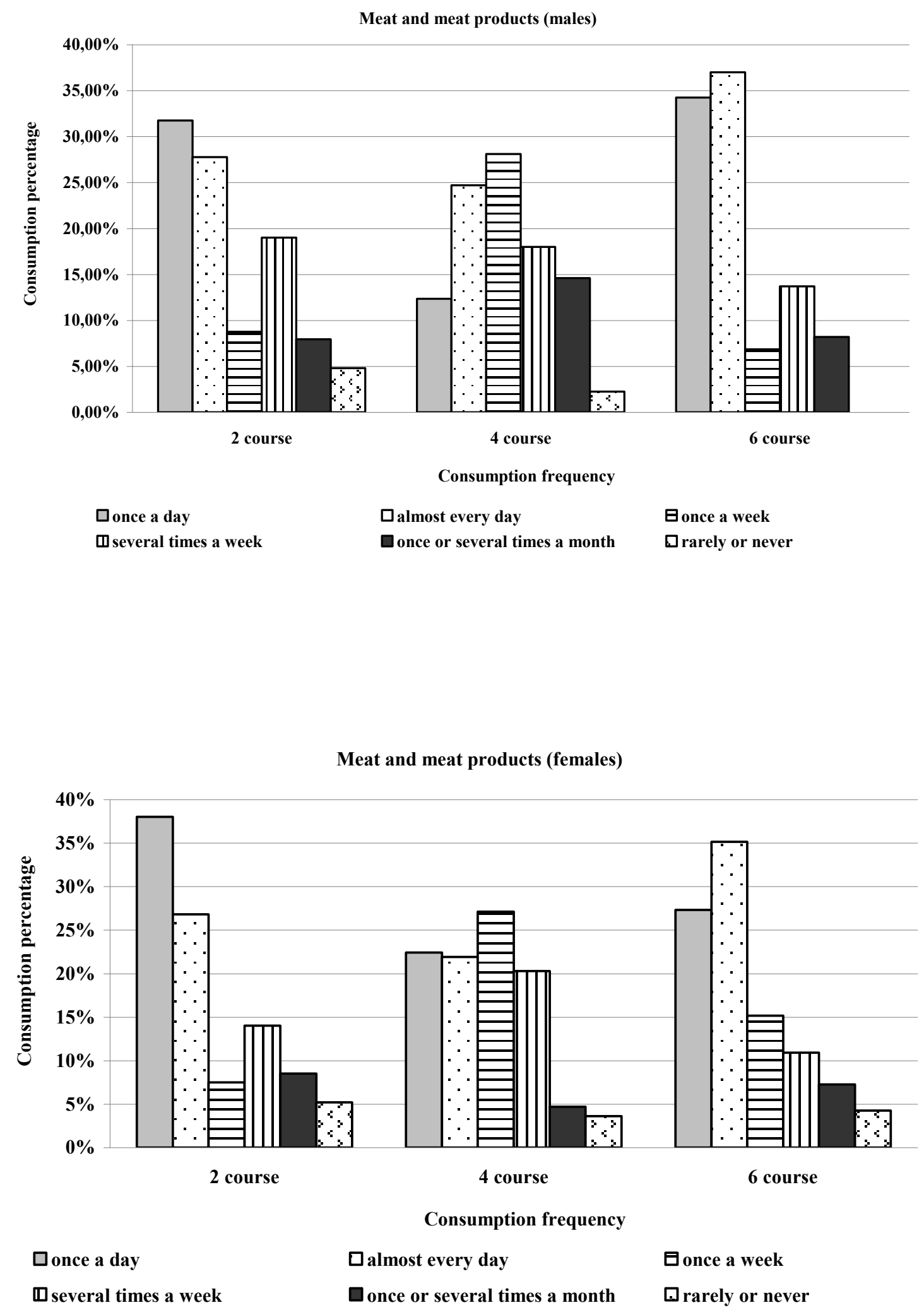

Fig. 1. Frequency of consumption of meat and meat products by medical students 


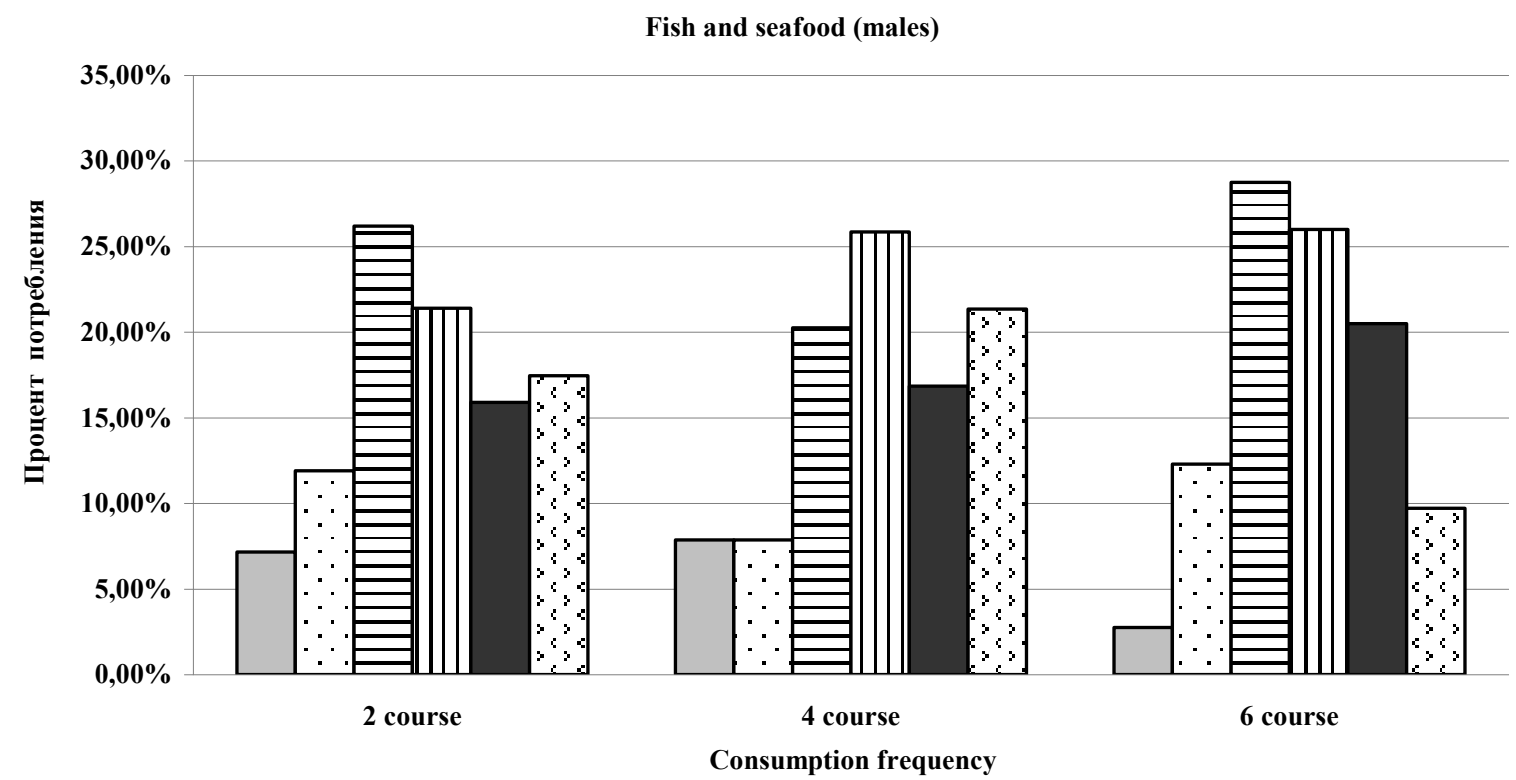

$\square$ once a day $\square$ almost every day $\boxminus$ once a week $\square$ several times a week $\square$ once or several times a month $\square$ rarely or never

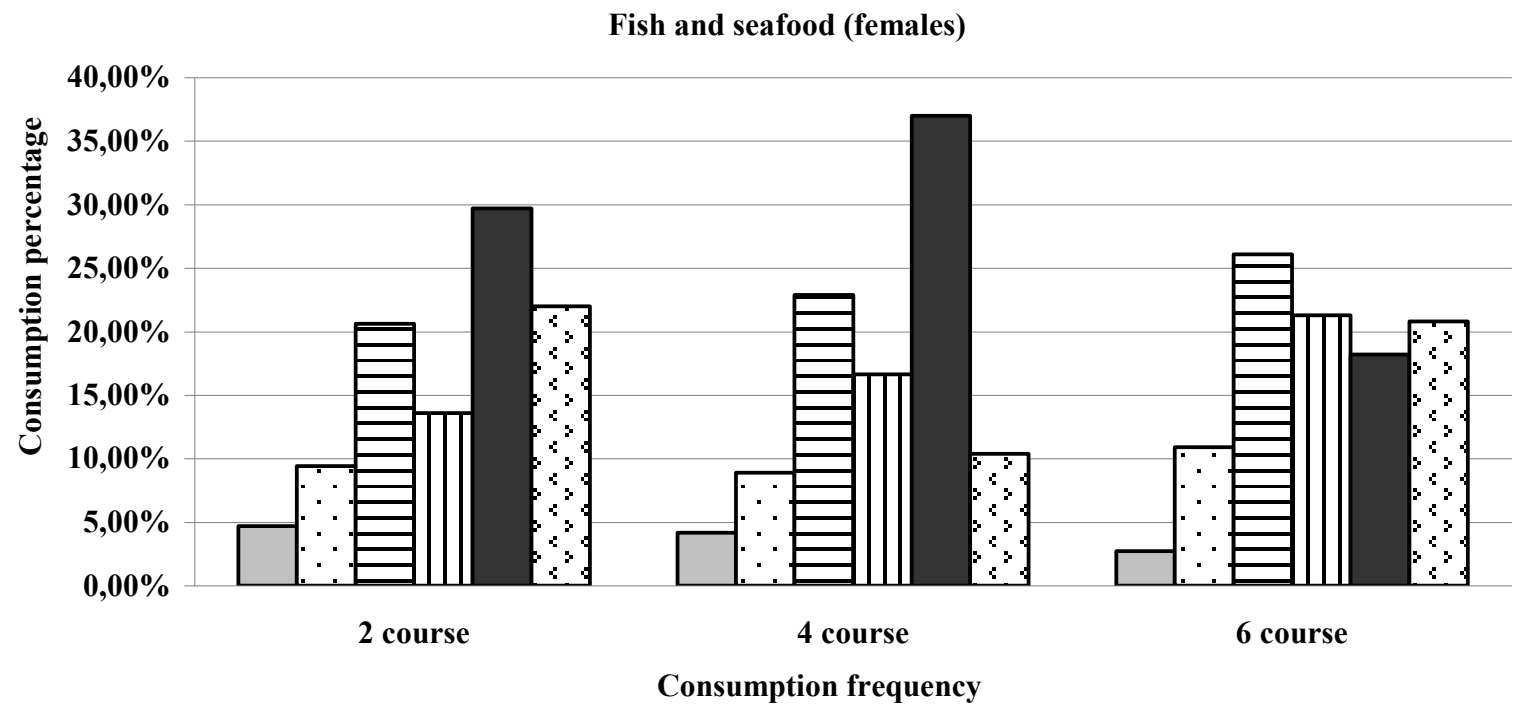
$\square$ once a day
Galmost every day
日once a week
U several times a week
口once or several times a month
๑rarely or never

Fig. 2. Frequency of consumption of fish and seafood by medical students

When assessing the frequency of consumption of milk and dairy products, it was revealed that $23.0 \%$ and $36.5 \%$, respectively, of male-respondents of the 2nd course consume them daily or almost every day, and $31.0 \%$ and $29.6 \%$, respectively, of femalerespondents of the 2 nd course; once a week or several times a week $-12.7 \%$ and $17.45 \%$ of the male-respondents and $6.6 \%$ and $18.7 \%$ of femalerespondents; once or several times a month, rarely or never $-6.35 \%$ and $4.0 \%$ of male-respondents and $8.9 \%$ and $5.2 \%$ of female-respondents; daily or almost every day $-28.1 \%$ and $20.25 \%$ of male- 
respondents, respectively of the 4th course and $24.5 \%$ and $39.6 \%$ of female-respondents, respectively of the 4th course; once a week or several times a week $-21.35 \%$ and $18.0 \%$ of male-respondents and $17.2 \%$ and $9.9 \%$ of female-respondents; once or several times a month, rarely or never $6.7 \%$ and $5.6 \%$ of male-respondents and $4.7 \%$ and $4.1 \%$ of female-respondents; daily or almost every day $-20.5 \%$ and $17.8 \%$, respectively, of male-res- pondents of the 6th course and $20.7 \%$ and $29.7 \%$ of female-respondents, respectively, of the 6th course; once or several times a week $-20.5 \%$ and $27.5 \%$ of male-respondents and $26.7 \%$ and $12.0 \%$ of - respondents; once or several times a month, rarely or never $-5.5 \%$ and $8.2 \%$ of male-respondents and $8.5 \%$ and $2.4 \%$ of female-respondents. Data on the frequency of consumption of milk and dairy products are presented in the form of a graph (Fig. 3).
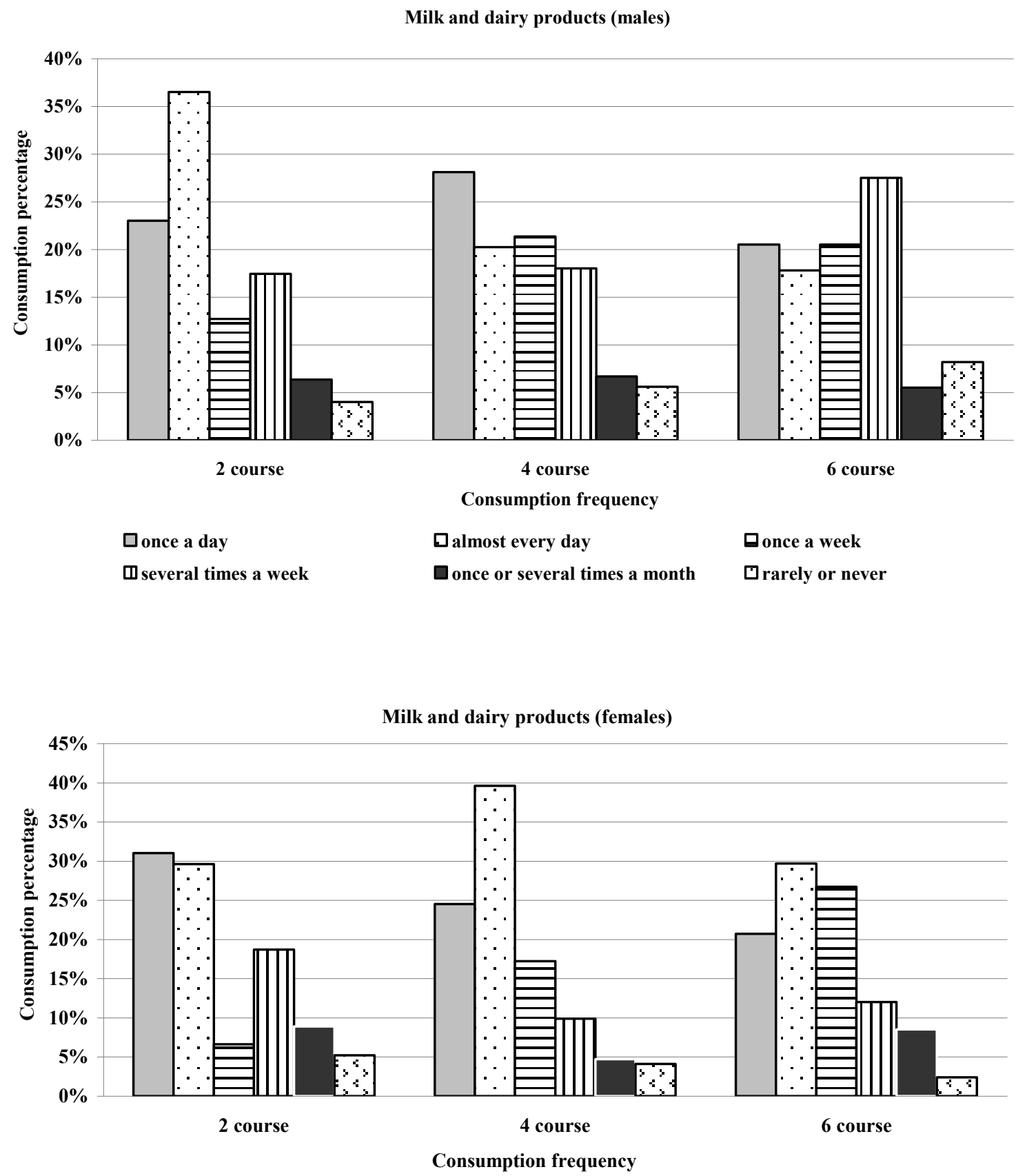

$\square$ once a day $\square$ almost every day $\boxminus$ once a week $\square$ several times a week $\square$ once or several times a month $\square$ rarely or never

Fig. 3. Frequency of consumption of milk and dairy products by medical students 
When assessing the frequency of consumption of eggs, it was found that $21.4 \%$ and $21.4 \%$, respectively, of male-respondents of the 2 nd course and $11.75 \%$ and $19.25 \%$ of female-respondents, respectively of the 2 course consume them daily; once a week or several times a week $-24.6 \%$ and $19.0 \%$ of male-respondents and $20.2 \%$ and $20.6 \%$ of female-respondents; once or several times a month, rarely or never $-8.0 \%$ and $5.6 \%$ of male-respondents and $10.8 \%$ and $17.4 \%$ of female-respondents; daily or almost every day $-18.0 \%$ and $19.1 \%$ of male-respondents, respectively, of the 4th course and $10.95 \%$ and $30.7 \%$ of female-respondents, respectively, of the 4th course; once a week or several times a week $-18.0 \%$ and $22.4 \%$ of male- respondents and $23.95 \%$ and $18.25 \%$ of femalerespondents; once or several times a month, rarely or never $-13.5 \%$ and $9.0 \%$ of male-respondents and $9.9 \%$ and $6.25 \%$ of female-respondents; every day or almost every day $-12.2 \%$ and $26.0 \%$, respectively, of male-respondents of the 6th course and $13.3 \%$ and $25.45 \%$ of the female-respondents, respectively, of the 6th course; once a week or several times a week $-22.0 \%$ and $22.0 \%$ of malerespondents and $24.85 \%$ and $20.7 \%$ of femalerespondents; once or several times a month, rarely or never $-9.6 \%$ and $8.2 \%$ of male-respondents and $10.9 \%$ and $4.8 \%$ of female-respondents. Data on the frequency of consumption of eggs are presented in the form of a graph (Fig. 4).

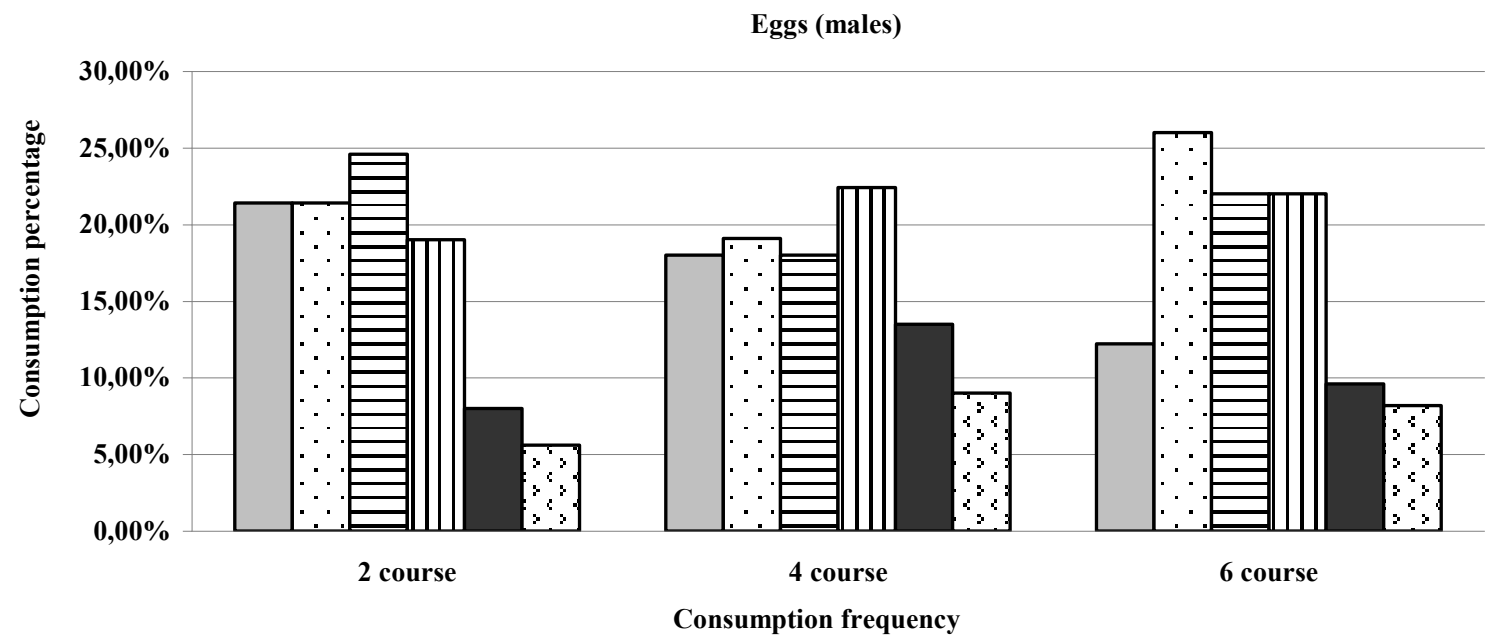

$\square$ once a day $\square$ almost every day $\square$ once a week $\square$ several times a week $\square$ once or several times a month $\square$ rarely or never

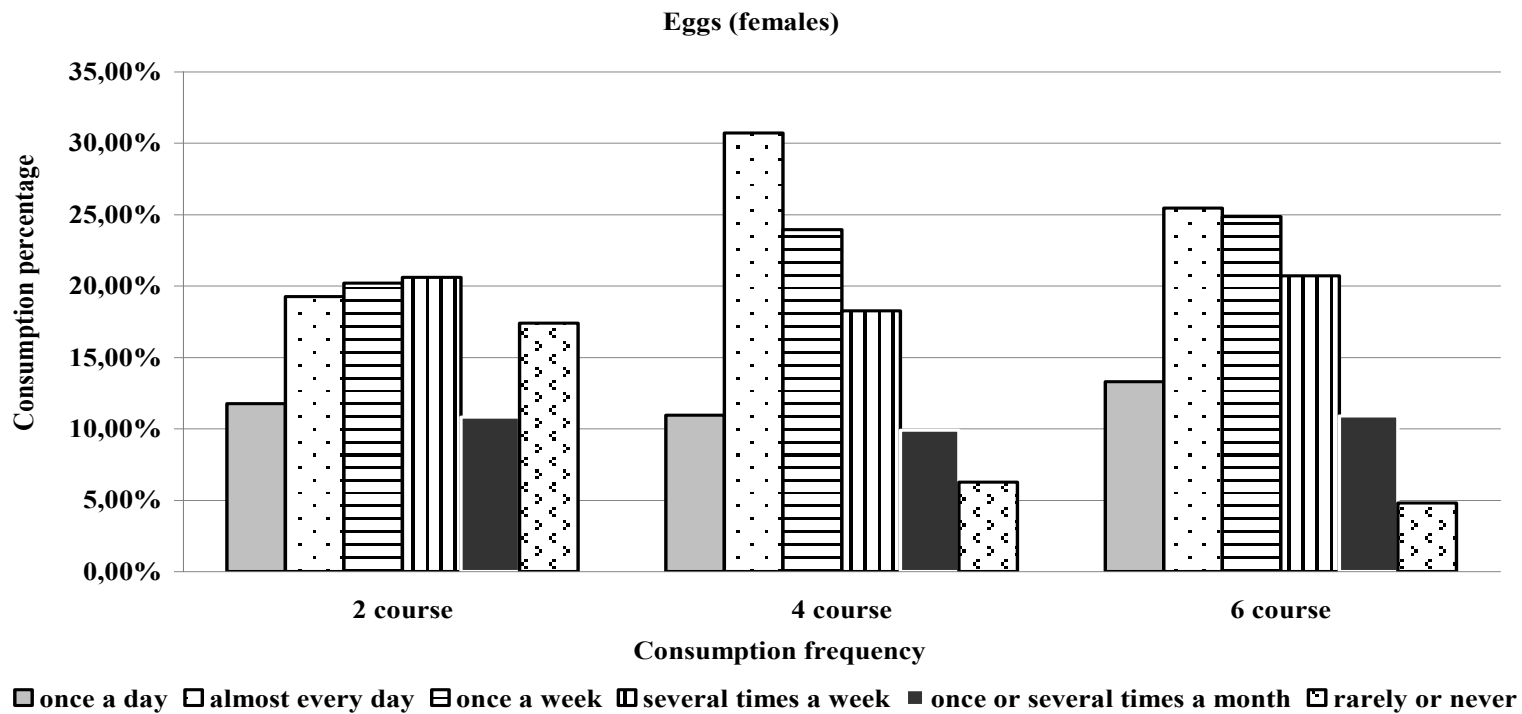

Fig. 4. Frequency of egg consumption by medical students 
When assessing the frequency of consumption of butter and lard, it was found that $16.7 \%$ and $22.25 \%$ of male-respondents, respectively of the 2 nd course and $6.6 \%$ and $13.2 \%$ of female-respondents, respectively of the 2nd course consume them once daily or almost every day; once a week or several times a week $-15.0 \%$ and $25.4 \%$ of the male respondents and $22.5 \%$ and $18.3 \%$ of female-respondents; once or several times a month, rarely or never $-14.3 \%$ and $6.35 \%$ of male-respondents and $10.3 \%$ and $29.1 \%$ of female-respondents; daily or almost every day $-18.0 \%$ and $22.4 \%$ of male-respondents, respectively of the 4 ht course and $5.7 \%$ and $6.7 \%$ of female-respondents, respectively of the 4th course; once a week or several times a week $-21.35 \%$ and
$16.85 \%$ of male-respondents and $10.4 \%$ and $28.7 \%$ of female-respondents; once or several times a month, rarely or never $-13.5 \%$ and $7.9 \%$ of malerespondents and $25.5 \%$ and $23.0 \%$ of femalerespondents; daily or almost every day $-17.8 \%$ and $27.5 \%$, respectively of male-respondents of the 6 th course and $10.3 \%$ and $29.0 \%$ of female-respondents, respectively of the 6 th course; once a week or several times a week $-15.0 \%$ and $16.4 \%$ of malerespondents and $16.36 \%$ and $19.4 \%$ of femalerespondents; once or several times a month, rarely or never $-12.3 \%$ and $11 \%$ of male-respondents and $10.3 \%$ and $15 \%$ of female-respondents. Data on the frequency of consumption of butter and lard are presented in the form of a graph (Fig. 5).
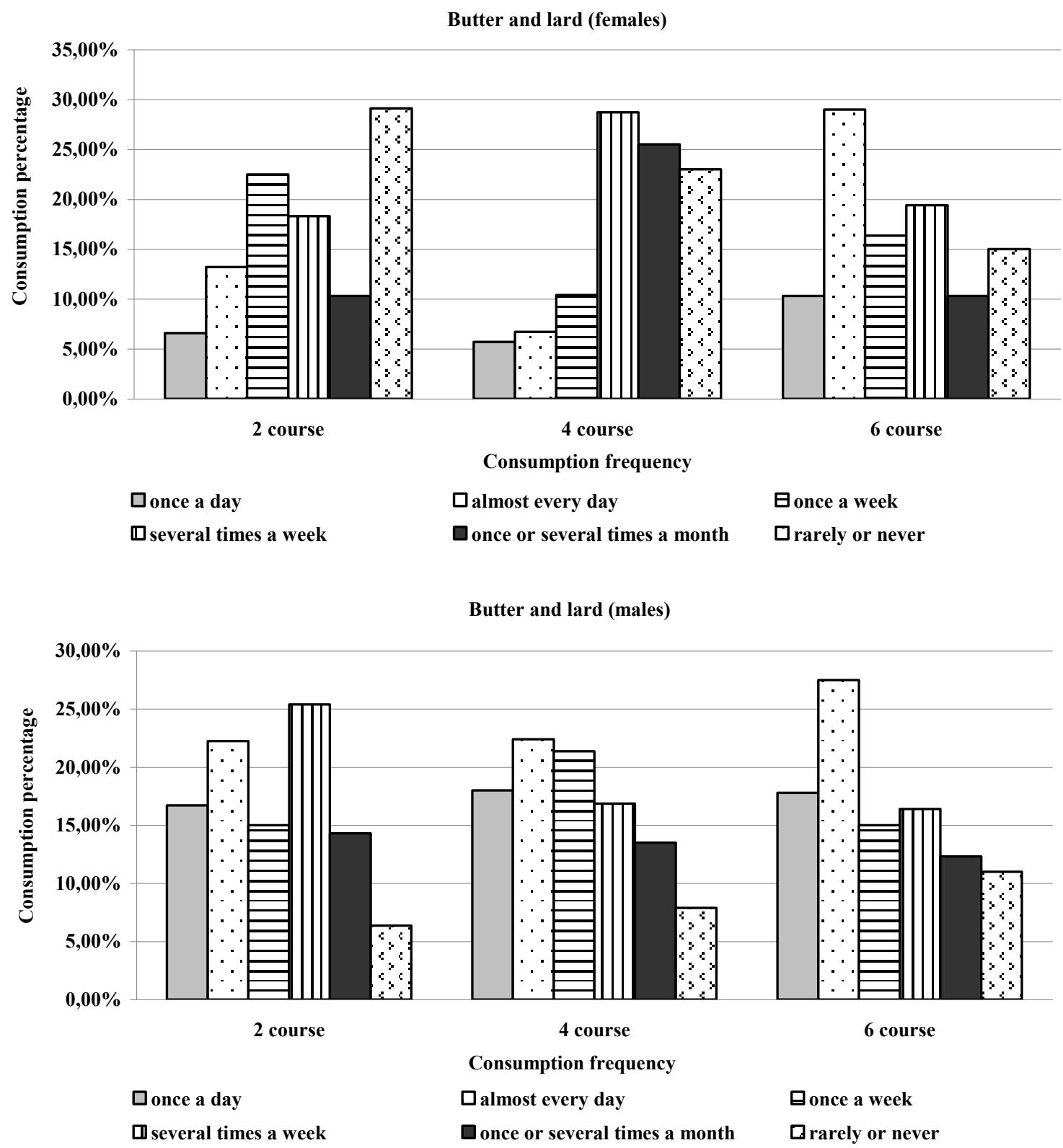

Fig. 5. Frequency of consumption of fat-containing products by medical students 


\section{CONCLUSIONS}

1. The obtained results make it possible to conclude that more than $2 / 3$ of diet of medical students does not meet the national recommendations on nutrition of the population by the frequency of consumption of food products of animal origin $[12,13]$. Less than a third of respondents, regardless of gender or course of study, include meat and meat products, milk and dairy products in their diet once a day or almost every day. Less than $1 / 5$ of respondents include fish and seafood, eggs and fatcontaining products daily.

2. The current situation may lead to the emergence of polynutrient deficiencies of nutrients of animal origin and hereafter - to nutritional diseases, which confirms the need for targeted correction of diet of medical students according to the frequency of consumption of food of animal origin.

\section{REFERENCES}

1. Hryhorenko A. [Methodical recommendations for general practitioners of family medicine on counseling patients about the basic principles of healthy eating]. Metodychni rekomendacii zgidno nakazu MOZ N 16 vid 14.01.2013. 2013;30. Ukrainian.

2. Yeltsova LB. [Hygienic assessment of the diet of medical students and justification of ways of its correction] Problemy harchuvannia. 2017;1:17-21. Ukrainian.

3. Yeltsova LB. [Monitoring of average daily consumption of bread, cereals and macaroni products in the diet of student youth]. IX International Scientifik and Practical Conference "International Trends in Science and Technology". Warsaw, Poland. 2019;10-16. Ukrainian.

4. Yeltsova LB. [The need for monitoring the main components of the life style of student youth]. Ecological and hygienic problems of human life. Conference. 2019;61-62. Ukrainian.

5. Yeltsova LB. [Substantiation of ways to improve the questionnaire method for assessing the actual nutrition of the population]. Medicni perspektivi. 2017;22(3):10412. Ukrainian. doi: https://doi.org/10.26641/23070404.2017.3.111935

6. Yeltsova LB, Omelchuk ST, Petrosian AA. [Estimation of average daily consumption of dairy and sour milk products in the diet of student youth]. Aktualni problemi suchasnoi medytsyny. 2018;13-19. Ukrainian. doi: https://doi.org/10.31718/2077-1096.18.4.13

7. Yeltsova LB, Omelchuk ST. [Estimation of average daily consumption of food products of animal origin in the diet of student youth]. Problemy viiskovoi okhorony zdorovia. Zbirnyk naukovykh prats Ukrainskoi viiskovo-medychnoi akademii. 2018;244-257. Ukrainian.
8. Yeltsova LB, Omelchuk ST, Aleksiichuk VD, Petrosian AA. [Prevention of hypovitaminosis and hypomicroelementosis in student youth]. Dovkillia ta zdorovia. 2018;53-57. Ukrainian.

9. [«Health 2020»: Fundamentals of the European Strategy to support the actions of the entire state and society in the interests of health and well-being]. Kopengagen: WHO, 2012. Ukrainian.

10. Matasar VI, Tsypriian LA et al. [Primary and secondary prevention of alimentary-dependent diseases]. Akademiia medychnyh nauk Ukrainy. 2007;80. Ukrainian.

11. Perederiy VG, Tkach SM. [Clinical evaluation of diet and nutrition in adults]. Pytanie $i$ zdorov'e. 2010;1:15-20. Russian.

12. Piven N. [Recommendations for healthy eating for adults]. Praktykuiuchyi likar. 2018;1:39-46. Ukrainian.

13. [Law of Ukraine "On Approval of the Standards of Physiological Needs of the Population of Ukraine in the Basic Nutrients and Energy"]. Ministerstvo ohorony zdorovia Ukrainy. 2017. Ukrainian.

14. Shvets OV. [The value of a sufficient and balanced diet in the prevention of the most dangerous diseases of our time]. Pitanie i zdorov'e. 2010;1:9-14. Russian.

15. Shvets OV, Bankovska NV. [Hygienic assessment of the actual nutrition of the population of Ukraine and the levels of consumption of the main groups of food products]. Ministerstvo ohorony zdorovia Ukrainy. Derzhavnyi naukovo-doslidnyi centr $\mathrm{z}$ problem gigieny harchuvannja. 2008;37. Ukrainian.

\section{СПИСОК ЛИТЕРАТУРЫ}

16. Григоренко А. Методичні рекомендації для лікарів загальної практики-сімейної медицини 3 приводу консультування пацієнтів щодо основних засад здорового харчування. Методичні рекомендації згідно наказу МО3 №16 від 14.01.2013. 2013. 30 с.

17. Сльцова Л. Б. Гігієнічна оцінка режиму харчування студентів-медиків та обгрунтування шляхів його корекції. Проблеми харчування. 2017. № 1. С. 17-21.
18. Сльцова Л. Б. Моніторинг середньодобового споживання хлібних, круп'яних та макаронних виробів у раціоні студентської молоді. IX International Scientifik and Practical Conference "International Trends in Science and Technology": матеріали конф., м. Варшава, Польща. 31 января 2019 р. Варшава, 2019. С. 10-16.

19. Сльцова Л. Б. Необхідність проведення моніторингу основних складових способу життя 
студентської молоді. Екологічні та гігієнічні проблеми сфери життєдіяльності людини: матеріали наук.практ. конф. $з$ міжнародною участю. 2019. С. 61-62.

20. Сльцова Л. Б., Омельчук С. Т. Обгрунтування шляхів удосконалення анкетно-опитувального методу оцінки фактичного харчування населення. Медичні перспективи. 2017. Т. 22. № 3. С. 104-112. DOI: https://doi.org/10.26641/2307-0404.2017.3.111935

21. Сльцова Л. Б., Омельчук С. Т., Петросян А. А. Оцінка середньодобового споживання молочних та кисломолочних продуктів харчування у раціоні студентської молоді. Актуальні проблеми сучасної медицини. Вісник Укр. мед. стомат. акад. 2018. С. 13-19. DOI: https://doi.org/10.31718/2077-1096.18.4.13

22. Сльцова Л. Б., Омельчук С. Т. Оцінка середньодобового споживання продуктів харчування тваринного походження у раціоні студентської молоді. Проблеми військової охорони здоров'я: збірник наукових праць Укр. військово-медичної академії. 2018. C. 244-257.

23. Сльцова Л. Б., Омельчук С. Т., Алексійчук В. Д., Петросян А. А. Профілактика гіповітамінозів та гіпомікроелементозів у студентської молоді. Довкілля та здоров'я. 2018. С. 53-57.

24. “Здоров’я-2020”: Основи Європейської стратегії у підтримку дій всієї держави і суспільства в інтересах здоров'я і благополуччя. Копенгаген: $С Р Б$ BOO3. 2012.

25. Первинна та вторинна профілактика аліментарнозалежних захворювань: метод. рек. / Матаcap I. Т. та ін. Київ: МOЗ України, АМН України. Укр. центр наук. мед. інформації та патентно-ліцензійної роботи, $2007.80 \mathrm{c}$

26. Передерий В. Г., Ткач С. М. Клиническая оценка диеты и питания у взрослых. Питание и здоровье. 2010. № 1. С. 15-20.

27. Півень Н. Рекомендації щодо здорового харчування дорослих. Практикуючий лікар. 2018. № 1. C. $39-46$.

28. Про затвердження Норм фізіологічних потреб населення України в основних харчових речовинах $\mathrm{i}$ енергії: Закон України від 03.09.2014 р. МОЗ України. Офіц. вид. Київ: Міністерство юстиції України, 2017.

29. Швец О. В. Значение достаточной и сбалансированной диеты в профилактике наиболее опасных болезней современности. Питание и здоровье. 2010. № 1. С. 9-14.

30. Швець О. В., Банковська Н. В. Гігієнічна оцінка фактичного харчування населення України та рівнів споживання основних груп харчових продуктів: метод. рек. Київ: MO3 України. ДП "Держ. науково-дослідний центр з проблем гігієни харчування", 2008. 37 с.

The article was received 2019.03.05 